\title{
Evaluation of the first level of care for tuberculosis control in Buenos Aires, Argentina*
}

\author{
Javier Mariani ${ }^{1}$, Daniel Ferrante², Gabriel Battistella ${ }^{3}$, Martín Langsam¹, Freddy Pérez $^{4}$, and Alejandro \\ Macchia $^{1}$
}

Suggested citation Mariani J, Ferrante D, Battistella G, Langsam M, Pérez F, Macchia A. Evaluation of the first level of care for tuberculosis control in Buenos Aires, Argentina. Rev Panam Salud Publica. 2021;45:e22. https://doi.org/10.26633/RPSP.2021.22

ABSTRACT Objective. Evaluate primary health care functions from the perspective of patients with tuberculosis from slums in the city of Buenos Aires, Argentina.

Methods. Cross-sectional observational study with adult patients with tuberculosis (TB) and without TB (NoTB), living in slums (S) and outside them (NoS). Participants' perceptions were evaluated using the Primary Care Assessment Tool for users (abbreviated version), which measures four main domains (first contact, ongoing care, coordination with specialists, and comprehensiveness) and selected secondary domains. A Likert scale was used, ranging from "No, not at all" (1 point) to "Yes, definitely" (4 points). Scores $\geq 3$ were considered to indicate adequate performance of functions. Averages were calculated for each domain, as well as two overall scores: with and without secondary domains.

Results. 83 participants were included (20 TB-S, 21 TB-NoS, 19 NoTB-S, and 23 NoTB-NoS). The evaluated functions were perceived as inadequate. The TB-S group gave the lowest overall scores, not reaching 3 points in any domain. There were no significant differences in domains or overall scores between groups. Participants with TB gave lower scores in all domains, except in family-centered care, where they gave a significantly higher score than NoTB participants. The overall score without secondary domains was lower for TB participants than for the NoTB groups.

Conclusions. According to the perception of participants with TB and without TB, primary health care functions are not satisfactory, either in slums or outside them.

Keywords $\quad$ Poverty areas; tuberculosis; quality of health care; primary health care; Argentina.

In the Sustainable Development Goals, the World Health Organization proposes an $80 \%$ reduction in the incidence of tuberculosis (TB) and a 90\% reduction in mortality from the disease by the year 2030 (1). The End TB Strategy, in turn, has set a target of reducing the two indicators by $90 \%$ and $95 \%$, respectively, between 2015 and $2035(2,3)$. The strategy rests on three key pillars to meet these targets, the first of which is integrated

\footnotetext{
* Official English translation from the original Spanish manuscript made by the Pan American Health Organization. In case of discrepancy, the original version shall prevail. Access to original manuscript: https://doi.org/10.26633/ RPSP.2020.156

1 Fundación GESICA, Buenos Aires, Argentina.凹 Javier Mariani, ja_mariani@ hotmail.com

2 Secretariat of Network Health Planning and Management, Ministry of Health of the city of Buenos Aires, Buenos Aires, Argentina.
}

patient-centered care and prevention, whose principles include adaptation of the interventions to the unique context of the epidemic and health setting (2).

Implementing this strategy in Argentina includes robust participation by the first level of care in a range of prevention, documentation, diagnostic, treatment, and monitoring activities at the community level (4).

\footnotetext{
3 Secretariat of Primary, Outpatient, and Community Care, Ministry of Health of the city of Buenos Aires, Buenos Aires, Argentina.

4 Department of Communicable Diseases and Environmental Determinants of Health, Pan American Health Organization, Washington, D.C., United States of America.
} 
This poses a real challenge related to the limitations of the Argentine health system and the social, economic, and demographic characteristics of the populations most affected by TB (5).

Since 2013, Argentina has documented an increase in the number and annual incidence rate of TB cases (5), which are concentrated in urban and peri-urban centers and, within them, among socioeconomically vulnerable groups. Most affected are people living in irregular settlements, especially slums $(5,6)$. Slums are groupings of makeshift dwellings constructed outside the legal framework on land owned by others (usually public land) and characterized by limited access to basic services (water, electricity, sewerage disposal) and overcrowding (7). In Buenos Aires, the most populous city in Argentina, 7.6\% of the population (or some 230,000 people) are slum dwellers (8). Furthermore, according to data computed between January 2016 and August 2018, 26.3\% of the city's TB cases (765 of 2,908 total cases) were concentrated in these slums, making them areas of high incidence (calculated by the authors with data from the National Health Surveillance System).

In response to the aforementioned observed increase in the number of cases, in 2017 the municipal government launched the Comprehensive Plan to Fight TB-largely relying on the first level of care-for documentation, prevention, and the treatment and monitoring of TB patients (9). The general objectives of this program are a comprehensive approach in primary care centers, evaluation and referral to pulmonologists specializing in TB (referrals and counter-referrals from and to primary care), and increased intersectoral efforts, monitoring, and ongoing training (9). Nonetheless, despite some improvements in process indicators after implementation of the plan (information on each case and the number of cases entered in the epidemiological surveillance systems by the first level of care), other results indicators still need improvement: in $35 \%$ of the 2,729 cases reported in Buenos Aires in 2018, the treatment modality was not indicated and the use of directly observed treatment was documented in only $18 \%(n=323)(10)$. This situation demonstrates the enormous challenge of implementing a community-based TB control program in the most vulnerable population group of a large city.

The objective of this study was to evaluate the primary health care functions of the public health system from the perspective of patients with $\mathrm{TB}$ and compare the perception of patients from the city's slums with that of patients from other areas of the city and participants without TB from both areas.

\section{MATERIALS AND METHODS}

A cross-sectional observational study was conducted. This article is part of a larger project in which functions at the first level of care for the treatment of TB were evaluated from the perspective of patients, health professionals, and managers and included both a quantitative and a qualitative component. This article reports the results of the quantitative component from the patients' perspective.

\section{Participants}

The participants were people over the age of 18 treated at the first level of care in the Buenos Aires public health system who had received a diagnosis of TB (through sputum-smear microscopy or a positive culture of a respiratory sample) in the year prior to their inclusion in the study. The control group consisted of patients who had received a diagnosis of bronchial asthma or chronic obstructive pulmonary disease in the past year; these diagnoses were used as a control, since they are respiratory diseases that require regular monitoring and not just a single visit to the health center. The participants were identified in health and community action centers (CeSAC), both in and outside slums. CeSAC are multipurpose centers for primary health care (PHC) and are staffed by general practitioners and a variable number of specialists. The study sample consisted of four groups of participants: patients with TB living in slums (TB-S), patients with TB not living in slums (TB-NoS), patients with other respiratory diseases living in slums (NoTB-S), and patients with other respiratory diseases not living in slums (NoTB-NoS). Although the comparison of primary interest was between TB-S and TB-NoS, it was judged that including participants without TB would make it possible to evaluate the effect of having a potentially stigmatizing disease (11).

\section{Evaluation tool}

To evaluate patients' perception of functions at the first level of care, Primary Care Assessment Tool (PCAT) questionnaires are often used (12). The PCAT was designed to evaluate the first level of care in health systems through their main functions and consists of four questionnaires that capture four different perspectives. The questionnaires are: PCAT-users/patients, for patients and users; PCAT-providers, for members of the health team, including health professionals; PCAT-centers, for PHC center directors; and PCAT-systems, for managers. These questionnaires have been used to evaluate the PHC functions of health systems for various diseases, including TB (13).

The abbreviated version of the PCAT-patients/users questionnaire used in this study has been translated and culturally adapted for Argentina and has been shown to have adequate psychometric properties (14-16). This tool has four main domains that reflect the essential functions of PHC: first contact, which includes the subdomains of PHC service utilization (1 question) and access to PHC centers (2 questions); ongoing care, which includes the subdomains of continuity of care (4 questions) and coordination of care (4 questions); coordination with specialists (1 question); and comprehensiveness, which includes the subdomains of services provided (3 questions) and services available (4 questions). It also contains two secondary domains that capture other PHC functions: family-centered care (2 questions) and community orientation (1 question). Finally, this questionnaire solicits information about interviewees' sex, age, employment status, and highest level of instruction and includes three questions to determine the degree to which interviewees identify with a health center or PHC physician (recognition of a center or professional as the one they go to for any health problem).

Each domain of the questionnaire is made up of questions that are answered using a Likert scale of 1 to 4 ("No, not at all"; Probably no; Probably yes; Yes, definitely), in addition to "Don't know". To analyze the responses, the scores in each domain were added up; the "Don't knows" were computed as 2 (16). The overall value was calculated in two ways: as the average score for all domains and the score for only the primary domains. A score of 3 or higher indicates the perception of adequate system orientation toward PHC (17). 


\section{Procedures}

Convenience sampling was performed with the potential participants accessible to the investigators.

During their consultations at the center, patients were invited by CeSAC professionals to participate in the study. When patients agreed to participate, an interview was arranged with the study investigators, who explained the study objectives and asked them to sign the informed consent form. The investigators subsequently administered the abbreviated PCAT-users questionnaire to all the participants. All interviews were conducted privately and in person in the CeSACs habitually used by the participants.

\section{Statistical analysis}

A sample of 20 participants per group was deemed to guarantee a greater-than- $90 \%$ power to detect a difference of at least 2 points in the overall score between groups, considering a standard deviation of 1.7 and a type I error of $5 \%$ in the comparison of the four groups (18).

The scores for each domain were calculated as the sum of the scores obtained for each participant in each domain, divided by the number of questions in the domain. The overall scores were calculated as the sum of all responses per participant divided by the total number of questions.

Absolute and relative frequencies were used to describe the categorical data. Continuous data were described through averages and standard deviations (SD) or medians and interquartile ranges (IQR), depending respectively on whether or not they followed a normal distribution. The normality assumption was evaluated through the Shapiro-Wilk test and the inspection of histograms and quantile-quantile plots. Categorical data were compared between groups through the chi-square test or Fisher's exact test, as appropriate. To compare the continuous data of more than two groups, the ANOVA or Kruskal-Wallis test was used, depending on the type of distribution. For post hoc comparisons, $p$-values adjusted by the Bonferroni method were employed; this method is used to keep the type I error at the desired level in cases where multiple comparisons are made. In comparisons of two groups, the Student's $t$-test or Mann-Whitney $U$ test was used in cases of normal and non-normal distribution, respectively.

In addition, analyses adjusted by the differences in demographic characteristics were performed. Multiple linear regression models were used for this purpose, with the scores as dependent variables and the groups as independent variables; demographic variables that showed association $(p<0.10)$ in the simple linear regression analysis were used as covariables.

All the analyses involved two-tailed tests, and a $p$-value of $<0.5$ was considered statistically significant. The R-3.6.1 package for MacOS was used for the analyses (19).

\section{Ethical considerations}

The study was approved by the Research Ethics Committee of Hospital de Agudos Juan P. Fernández (CEI_201910) and by the Ethics Review Committee of the Pan American Health Organization (PAHO-2019-02-0016). All participants signed an informed consent form in which they agreed to participate in the study. Two authors had access to the data and vouch for their integrity. To maintain anonymity, the PCAT forms were completed anonymously and entered in the database by people who did not participate in the interviews, with no identification of the participants.

\section{RESULTS}

From 19 June to 26 August 2019, 83 participants were included (20 TB-S, 21 TB-NoS, 19 NoTB-S, and 23 NoTB-NoS).

Although differences were observed among the groups in terms of the distribution by age, sex, and employment status (Table 1), there were no significant differences with the participants in the control groups without TB.

Half the participants with TB were men whose median age was 33.0 years; $43.9 \%$ had a complete primary education or less as their highest level of instruction; 34.1\% were unemployed; and $61.0 \%$ strongly identified with their PHC center or medical professional.

\section{Perception of the system's PHC orientation}

Table 2 shows that the overall PCAT scores for both the entire study sample and each group are under 3, with no significant differences among groups; considering the participants as a whole, no individual domain attained an average of 3 .

The TB-S group had the lowest overall scores, though without statistically significant differences with the rest. Moreover, in this group, no domain achieved a score of 3, indicating a perception of adequate system functioning. The domains that attained values of 3 or higher in the groups were: family-centered care in the TB-NoS group, ongoing care in the NoTB-S group, and coordination in the NoTB-NoS group. Nonetheless, there were no statistically significant differences among the groups in any of the individual domains or overall scores (Figure 1).

Figure 2 shows that less than $50 \%$ of participants in all groups had average overall scores of 3 or higher. No significant differences were observed in the comparisons between participants with TB in and outside slums (Table 3).

The results did not change with adjustment for demographic differences.

\section{Comparison between participants with and without TB}

Participants with a diagnosis of TB had lower values in the overall score and the majority of domains than those without $\mathrm{TB}$, although without statistical significance (Table 4). In the overall score without secondary domains, participants with with TB had a significantly lower average than those without TB. Furthermore, in the family-centered care domain, the participants with TB had a significantly higher average than those without TB. In this analysis, only the family-centered care domain had an average of 3 , and this was observed in the patients with TB (Table 4).

\section{DISCUSSION}

The results of this study indicate that, from the perspective of health system users with TB, PHC functions in the health system are unsatisfactory. This perception, moreover, was consistent across domains and the four groups of patients included. 
TABLE 1. Sociodemographic characteristics of participants in the study on the first level of care for tuberculosis (TB) control, by study group, Buenos Aires, 2019

\begin{tabular}{|c|c|c|c|c|c|c|}
\hline \multirow[b]{2}{*}{ Variable } & \multirow[b]{2}{*}{ All groups } & \multicolumn{5}{|c|}{ Study group } \\
\hline & & With TB in slums ${ }^{\mathrm{a}}$ & With TB outside slums & $\begin{array}{l}\text { With other respiratory } \\
\text { diseases in slums }\end{array}$ & $\begin{array}{l}\text { With other respiratory } \\
\text { diseases outside slums }\end{array}$ & $p^{b}$ \\
\hline Number of participants & 83 & 20 & 21 & 19 & 23 & \\
\hline \multicolumn{7}{|l|}{ Sex, $n(\%)$} \\
\hline Male & $30(36.1)$ & $13(65.0)$ & $9(42.9)$ & $4(21.0)$ & $4(17.4)$ & $0.010^{d}$ \\
\hline \multicolumn{7}{|l|}{ Schooling, $n(\%)$} \\
\hline Less than primary & $9(10.8)$ & $4(20.0)$ & $2(9.5)$ & $3(15.8)$ & $0(0.0)$ & $0.206^{\mathrm{d}}$ \\
\hline Complete primary & $17(20.5)$ & $5(25.0)$ & $7(33.3)$ & $1(5.2)$ & $4(17.4)$ & \\
\hline Incomplete secondary & $20(24.1)$ & $6(30.0)$ & $2(9.5)$ & $5(26.3)$ & $7(30.4)$ & \\
\hline Complete secondary & $26(31.3)$ & $4(20.0)$ & $7(33.3)$ & $6(31.6)$ & $9(39.2)$ & \\
\hline More than secondary & $11(13.3)$ & $1(5.0)$ & $3(14.4)$ & $4(21.1)$ & $3(13.0)$ & \\
\hline Worker & $34(41.0)$ & $9(45.0)$ & $11(52.4)$ & $8(42.1)$ & $6(26.1)$ & \\
\hline Retiree & $12(14.5)$ & $0(0.0)$ & $1(4.8)$ & $0(0.0)$ & $11(47.8)$ & \\
\hline \multicolumn{7}{|l|}{ Identification, $n(\%)^{\mathrm{b}}$} \\
\hline None & $13(15.7)$ & $6(30.0)$ & $6(28.6)$ & $0(0.0)$ & $1(4.3)$ & $0.029^{d}$ \\
\hline Weak & $11(13.2)$ & $1(5.0)$ & $3(14.3)$ & $4(21.1)$ & $3(13.0)$ & \\
\hline Strong/Very strong & 59 (71.1) & $13(65.0)$ & $12(57.1)$ & $15(78.9)$ & $19(82.7)$ & \\
\hline
\end{tabular}

Source: Authors, based on the results obtained.

a Slums: groupings of makeshift dwellings constructed outside the legal framework on land owned by others and characterized by limited access to basic services and overcrowding Identification: degree to which participants can identify a primary health care professional or center as their service provider for health problems.

- The $p$-values correspond to the ANOVA test.

${ }^{a}$ The $p$-values correspond to Fisher's exact test.

TABLE 2. Responses to the Primary Care Assessment Tool (PCAT)-users questionnaire in the study on the first level of care for tuberculosis (TB) control, by study group, Buenos Aires, 2019

\begin{tabular}{|c|c|c|c|c|c|c|}
\hline \multirow[b]{2}{*}{ Domain or variable } & \multirow[b]{2}{*}{ All groups } & \multicolumn{5}{|c|}{ Study group } \\
\hline & & With TB in slums ${ }^{\mathrm{a}}$ & With TB outside slums & $\begin{array}{l}\text { With other respiratory } \\
\text { diseases in slums }\end{array}$ & $\begin{array}{l}\text { With other respiratory } \\
\text { diseases outside slums }\end{array}$ & $p^{b}$ \\
\hline Number of participants & 83 & 20 & 21 & 19 & 23 & \\
\hline Ongoing care, average (SD) & $2.8(0.6)$ & $2.6(0.6)$ & $2.9(0.5)$ & $3.0(0.6)$ & $2.8(0.6)$ & 0.133 \\
\hline Coordination, average (SD) & $2.8(1.0)$ & $2.5(1.0)$ & $2.9(0.9)$ & $2.9(1.1)$ & $3.0(0.9)$ & 0.411 \\
\hline Comprehensiveness, average (SD) & $2.7(0.8)$ & $2.8(0.9)$ & $2.4(0.7)$ & $2.7(0.7)$ & $2.9(0.8)$ & 0.158 \\
\hline Community orientation, average $(S D)^{c}$ & $1.8(1.0)$ & $2.0(1.2)$ & $1.7(0.8)$ & $2.0(1.2)$ & $1.6(0.9)$ & 0.472 \\
\hline Overall PCAT, average (SD) & $2.7(0.5)$ & $2.6(0.7)$ & $2.6(0.3)$ & $2.8(0.5)$ & $2.8(0.5)$ & 0.566 \\
\hline $\begin{array}{l}\text { Overall PCAT without secondary } \\
\text { domains, average (SD) }\end{array}$ & $2.7(0.5)$ & $2.6(0.7)$ & $2.6(0.4)$ & $2.8(0.5)$ & $2.9(0.5)$ & 0.187 \\
\hline
\end{tabular}

Source: Authors, based on the results obtained.

Note: SD: standard deviation.
to Slums: groupings of makeshift dwellings constructed outside the legal framework on land owned by others and characterized by limited access to basic services and overcrowding

b $p$-values correspond to the ANOVA test.

Secondary domain.

It should be noted that among the participants with TB living in slums, no individual domain or overall score attained the minimum value that would indicate satisfactory first-level functioning.

No studies have been found that evaluate health system orientation toward primary care for TB treatment in slum-dwelling populations; thus, to the best of our knowledge, this study is the first to do so from the patients' perspective. A five-city study in Brazil that included patients with TB and used a local adaptation of the PCAT tool for TB reported unsatisfactory results in the northeast region (which included two cities) for the first contact, comprehensiveness, and familycentered care domains, and satisfactory results for ongoing care and coordination (20). Furthermore, in the three cities in 
FIGURE 1. Distribution of average scores by main domains of the Primary Care Assessment Tool (PCAT)-users questionnaire in the study on the first level of care for tuberculosis (TB) control, by groupa, Buenos Aires, 2019

A: First contact domain; B: Ongoing care domain; C: Coordination domain; D: Comprehensiveness domain; E: Overall score; F: Overall score without secondary domains ${ }^{c}$
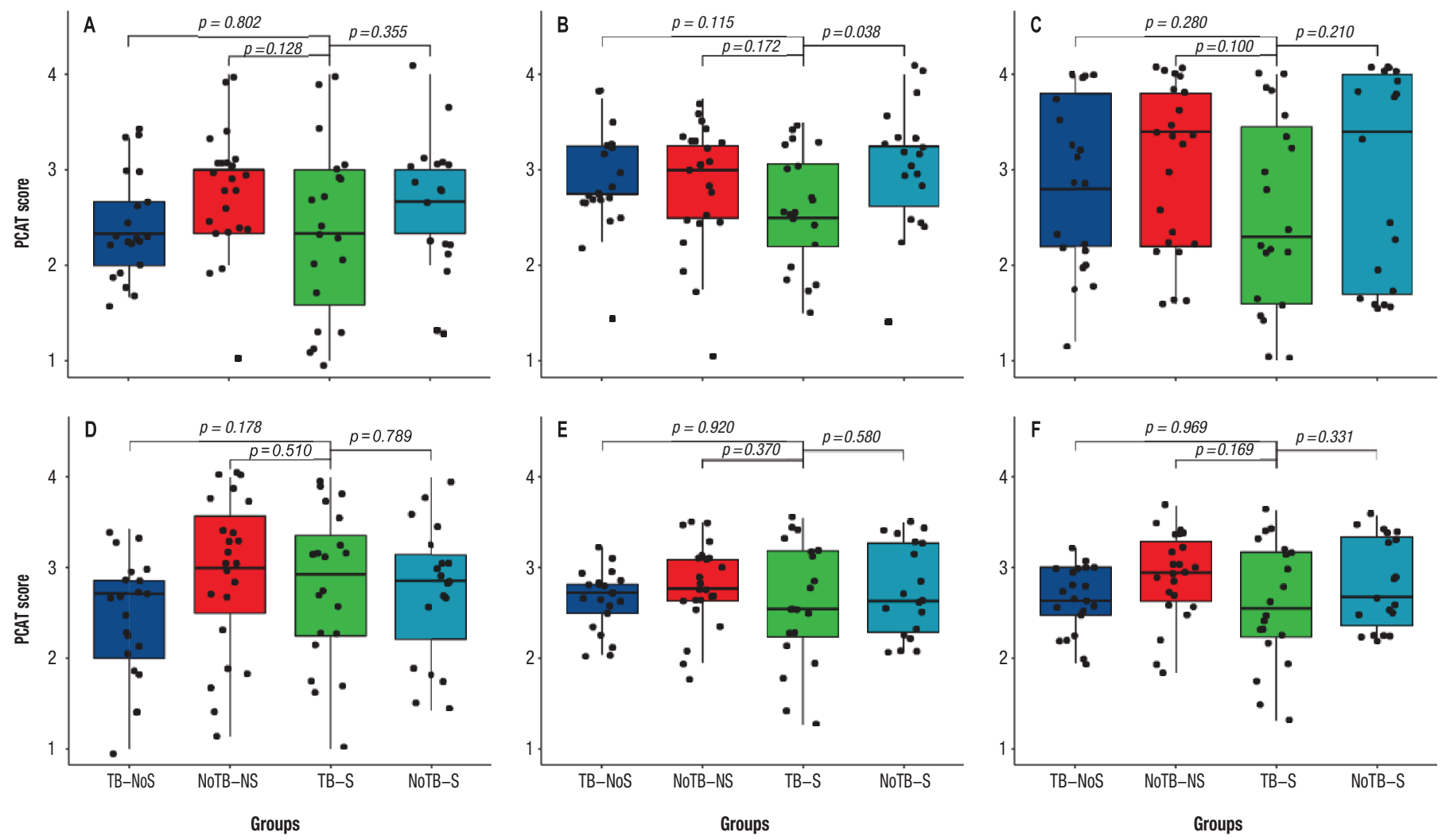

Groups

Source: Authors, based on the results obtained.

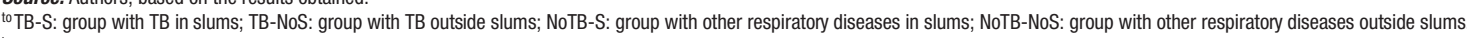

${ }^{b}$ The $p$-values correspond to the test of the Student's $t$ for comparisons in pairs of groups.

${ }^{\mathrm{C}}$ The secondary domains were family-centeredcareand community orientation.

the southeast, the results were satisfactory in all domains of the questionnaire (20). This study included PHC centers and centers specializing in TB treatment (in general, hospitals with highly qualified human and technical resources), without differentially disaggregating the results; thus, it is hard to compare these results with those of this study.

Other studies in South Africa, Malawi, Hong Kong, and Shanghai that used the PCAT tool to evaluate health systems from the users' perspective found, as in this study, unsatisfactory average values for several domains (21-23). Nevertheless, none of these studies focused on vulnerable populations with TB.

TB particularly affects the poorest and most vulnerable groups, and strengthening the first level of care to achieve universal health care is the best strategy for ending the disease $(24,25)$. This includes guaranteeing access to health services for the entire population, prioritizing the needs of groups with greater need, avoiding out-of-pocket health expenditures with complete publicly funded coverage, and increasing investment in primary health care (24). Evaluating the health system from the users' perspective is useful for identifying opportunities for improvement, particularly in light of the adverse TB incidence and mortality trends observed in Argentina (4).
Users' perception of the primary health care system is important to the evaluation of the quality of services and makes it possible to identify specific aspects that should be addressed to improve outcomes (26). Although there are numerous instruments for evaluating first-level functions in health systems, the PCAT was used because of its adequate psychometric properties and cross-cultural validation and adaptation in Argentina $(14,15,27)$.

The first-contact domain, which covers service utilization and access to consultations in primary care, has proven especially difficult in the case of TB and obtained the lowest score in the TB-S group (14). In other contexts, the first-contact limitations were linked not only to geographic access but to the availability of both consultations with health professionals adequately trained in management of the disease and the necessary technologies for timely diagnosis $(14,28)$. Similarly, the results for the other domains indicate the need to improve aspects related to coordination, ongoing care, and comprehensiveness-services available and services provided - in patient care (patient-centered care). According to the patients with $\mathrm{TB}$, family-centered care was adequate (although the score was higher outside slums); this may be 
FIGURE 2. Frequency of acceptance scores by main and secondary domains ${ }^{a}$ of the Primary Care Assessment Tool (PCAT)-users in the study on the first level of care for tuberculosis (TB) control, by group ${ }^{b}$, Buenos Aires, 2019c

A: First contact domain; B: Ongoing care domain; C: Coordination domain; D: Comprehensiveness domain; E: Family-centered care; F: Community orientation; G: Overall score; H: Overall score without secondary domains
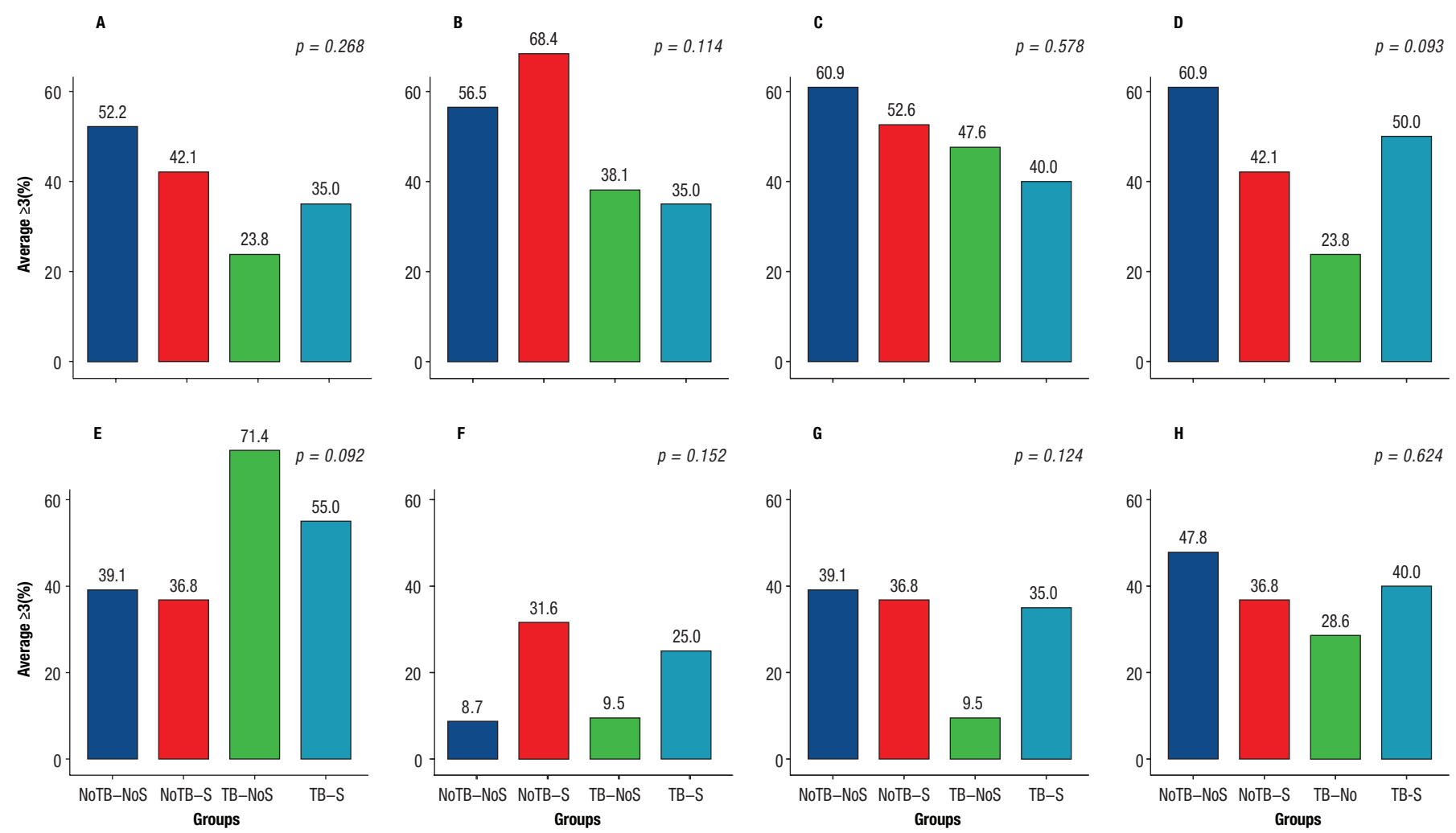

F

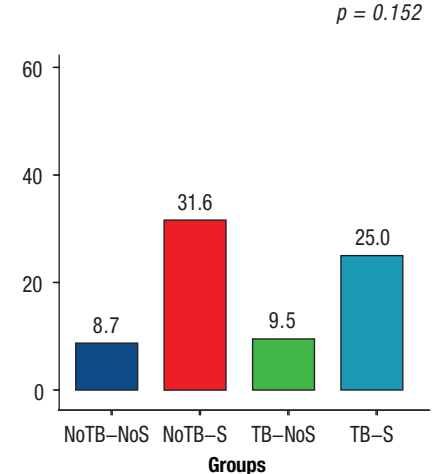

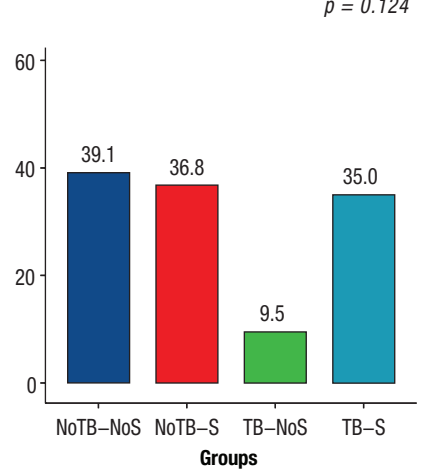

H

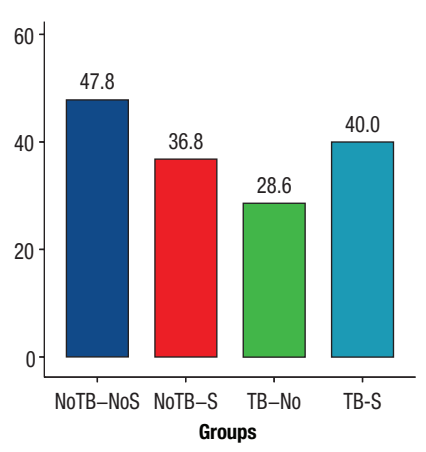

Source: Authors, based on the results presented.

a The secondary domains were family-centered care and community orientation.

${ }^{\mathrm{b}}$ TB-S: group with TB in slums; TB-NoS: group with TB outside slums; NoTB-S: group with other respiratory diseases in slums; NoTB-NoS: group with other respiratory diseases outside slums.

'The $p$-values correspond to the chi-square test (null hypothesis: there is no difference among the groups), except for the community orientation domain, which was compared among groups using Fisher's exact test.

TABLE 3. Responses to the Primary Care Assessment Tool (PCAT)-users questionnaire in the study on the first level of care for tuberculosis (TB) control, by place of residence, Buenos Aires, 2019

\begin{tabular}{lccc}
\multicolumn{1}{c}{ Variable } & $\begin{array}{c}\text { With TB in } \\
\text { slums }\end{array}$ & $\begin{array}{c}\text { With TB } \\
\text { outside slums }\end{array}$ & $p^{\mathrm{b}}$ \\
Number of participants & 20 & 21 & \\
First contact, average (SD) & $2.3(0.9)$ & $2.4(0.5)$ & 0.744 \\
Ongoing care, average (SD) & $2.6(0.6)$ & $2.9(0.5)$ & 0.105 \\
Coordination, average (SD) & $2.5(1.0)$ & $2.9(0.9)$ & 0.270 \\
Comprehensiveness, average (SD) & $2.8(0.9)$ & $2.4(0.7)$ & 0.170 \\
$\begin{array}{l}\text { Family-centered care, average (SD) } \\
\text { Community orientation, average }\end{array}$ & $2.9(1.3)$ & $3.2(1.1)$ & 0.367 \\
$\quad$ (SD) & $2.0(1.2)$ & $1.7(0.8)$ & 0.296 \\
$\begin{array}{l}\text { Overall PCAT score, average (SD) } \\
\text { Overall PCAT score without secondary } \\
\text { domains, average (SD) }\end{array}$ & $2.6(0.7)$ & $2.6(0.3)$ & 0.770 \\
\hline
\end{tabular}

TABLE 4. Responses to the Primary Care Assessment Tool (PCAT)-users questionnaire in the study on the first level of care for tuberculosis (TB) control, by patient's clinical status, Buenos Aires, 2019

\begin{tabular}{|c|c|c|c|}
\hline Variable & With TB & Without TB & $p^{a}$ \\
\hline Number of participants & 41 & 42 & \\
\hline First contact, average (SD) & $2.4(0.7)$ & $2.7(0.7)$ & 0.055 \\
\hline Ongoing care, average (SD) & $2.7(0.6)$ & $2.9(0.6)$ & 0.168 \\
\hline Coordination, average (SD) & $2.7(1.0)$ & $3.0(1.0)$ & 0.222 \\
\hline Comprehensiveness, average (SD) & $2.6(0.8)$ & $2.8(0.8)$ & 0.174 \\
\hline Approach family, average (SD) ${ }^{\mathrm{b}}$ & $3.0(1.2)$ & $2.4(1.2)$ & 0.022 \\
\hline $\begin{array}{l}\text { Community orientation, } \\
\text { average }(S D)^{b}\end{array}$ & $1.8(1.0)$ & $1.8(1.1)$ & 0.85 \\
\hline PCAT global, average (SD) & $2.6(0.5)$ & $2.8(0.5)$ & 0.443 \\
\hline $\begin{array}{l}\text { Global PCAT without secondary } \\
\text { domains, }\end{array}$ & $2.6(0.5)$ & $2.9(0.5)$ & 0.033 \\
\hline
\end{tabular}


related to the search for cohabiting contacts and to the planning of treatment jointly with that of other members of the family group (29).

\section{Limitations}

This study has several limitations that should be taken into account when interpreting the results. The sample was not random, since the study employed convenience sampling with patients who were in contact with the health system and agreed to participate in an interview with a member of the research team; this may have resulted in a group of patients with a more positive perception of the health system. Furthermore, the interviews were in-person, which could have biased the responses toward a favorable perception of the system. In both cases, however, the results would be representing a more optimistic scenario, which would indicate that the challenges and need for improvements could be even greater. The instrument used was not specifically designed to evaluate PHC functions for patients with TB. Nevertheless, the decision was made to use the abbreviated version of the general PCAT because of its locally validated adaptation and adequate psychometric properties, in addition to its extensive international use, which permits comparisons and the identification of problems common to other contexts. While there is a version of the PCAT for TB, it is only validated in

Portuguese and is not culturally adapted to Argentina (30).

Another limitation is the insufficient power to detect small differences among groups. Although the size of the sample for each group should guarantee a greater than $90 \%$ power to detect at least a 2-point difference in the overall score among the groups, a study with more participants could identify differences that are smaller but relevant from a planning standpoint.

The groups of participants differed in their baseline characteristics, which could reflect differences in the characteristics of the people they represent. Even though those baseline differences could explain the results in perceptions of PHC, the analyses adjusted by demographic factors did not change the results.

\section{CONCLUSIONS}

The results of this study indicate that, based on the perceptions of the participants with and without $\mathrm{TB}$, the performance of functions at the first level of care - the health system's vehicle for implementing the Comprehensive Plan to Fight TB - is unsatisfactory, both in and outside slums. No significant differences in perceptions were found in and outside slums, underscoring the need to address both contexts to improve first-level functions and thereby improve current indicator results and bring us nearer to TB elimination.

Authors' contributions. JM, DF, GB, ML, FP, and AM designed the original study and planned the experiments. JM, ML, and AM collected the data. JM, FP, and AM analyzed the data. All the authors interpreted the results, wrote and reviewed the manuscript, and approved the final version.

Acknowledgements. The authors would like to thank Drs. Karin Kopitowski and Mariela Weisbrot for their collaboration and provision of the PCAT version adapted for Argentina.

Conflicts of interest. The authors declare that they have no conflicts of interest.

Funding. This research was funded by the UNICEF/UNDP/ World Bank/WHO Special Program for Research and Training in Tropical Diseases (TDR), a program co-sponsored by the World Health Organization (WHO) as part of the call for proposals 'Embedding Research for the Sustainable Development Goals' initiative. This funding source has not influenced the collection, analysis, or interpretation of data.

Disclaimer. The authors hold sole responsibility for the views expressed in this manuscript, which may not represent the opinion or the policy of the RPSP/PAJPH or the Pan American Health Organization.

\section{REFERENCES}

1. United Nations. Transforming our world: the 2030 Agenda for Sustainable Development: Sustainable Development Knowledge Platform. New York: UN; 2015 [cited 5 May 2020]. Available at: https://sustainabledevelopment.un.org/post2015/transformingo urworld

2. World Health Organization. The End TB Strategy. Geneva: WHO; 2015 [cited 5 May 2020]. Available at: https://www. who.int/tb/ End_TB_brochure.pdf?ua $=1$

3. Uplekar M, Weil D, Lonnroth K, Jaramillo E, Lienhardt C, Dias HM, et al. WHO's new End TB Strategy. Lancet. 2015;385(9979):1799-801. doi: http:/ / doi.org/10.1016/S0140-6736(15)60570-0

4. Ministerio de Salud de la Nación. Plan Estratégico Nacional para el Control de la Tuberculosis en Argentina. Buenos Aires: MSAL; 2019 [cited 10 May 2020]. Available at: http:/ / www.msal. gob.ar/images / stories/bes/graficos /0000001434cnt-2019-03-28_plan-estrategico -control-tuberculosis.pdf

5. Ministerio de Salud de la Nación. Boletín sobre tuberculosis en la Argentina. Buenos Aires: MSAL; 2019 [cited 12 May 2020]. Available at: http://www.msal.gob.ar/images/stories/bes/gra-ficos /0000001436cnt-2019-03_boletin-epidemiologico_tuberculosis .pdf
6. Goldberg A. Factores socioculturales en el proceso asistencial de pacientes con tuberculosis del Instituto Vaccarezza del Hospital Muñiz, 2009. Rev Argent Salud Publica. 2010;1(5):13-21.

7. Ezeh A, Oyebode O, Satterthwaite D, Chen YF, Ndugwa R, Sartori J, et al. The history, geography, and sociology of slums and the health problems of people who live in slums. Lancet. 2017;389(10068):547-58.doi:http://doi.org/10.1016/S0140-6736(16) 31650-6

8. Gobierno de la Ciudad de Buenos Aires. Porcentaje de viviendas habitadas, hogares y población en villas de emergencia sobre el total de la Ciudad. Años 2006/2018. Buenos Aires: Dirección General de Estadísticas y Censos; 2019 [cited 15 May 2020]. Available at : https: / / www.estadisticaciudad.gob.ar/eyc/?p=50392

9. Ministerio de Salud de la Ciudad Autónoma de Buenos Aires. Plan integrado de abordaje de la tuberculosis. Bol Epidemiol Semanal. 2018; SE 22 [cited 12 May 2020]. Available at: https:/ / www.buenosaires.gob.ar/sites/gcaba/files/bes_95_se_22_vf.pdf

10. Ministerio de Salud de la Ciudad Autónoma de Buenos Aires. Vigilancia de la tuberculosis. Bol Epidemiol Semanal. 2019; SE 4 [cited 16 May 2020]. Available at: https://www.buenosaires. gob .ar/sites/gcaba/files/bes_129_se_4_vf.pdf 
11. Furin J, Cox H, Pai M. Tuberculosis. Lancet. 2019;393(10181):164256. doi: http://doi.org/10.1016/S0140-6736(19)30308-3

12. Shi L, Starfield B, Xu J. Validating the Adult Primary Care Assessment Tool. J Fam Pract. 2001;50(2):161-75.

13. De Sá LD, Scatena LM, Rodrigues RA, Nogueira JA, Silva AO, Villa TC. Gateway to the diagnosis of tuberculosis among elders in Brazilian municipalities. Rev Bras Enferm. 2015;68(3):408-14. doi: http://doi.org/10.1590/0034-7167.2015680313i

14. Vázquez Peña F, Harzheim E, Terrasa S, Berra S. Psychometric validation in Spanish of the Brazilian short version of the Primary Care Assessment Tools-user's questionnaire for the evaluation of the orientation of health systems towards primary care. Aten Primaria. 2017;49(2):69-76. doi: http://doi.org/10.1016/j.aprim.2016 .04 .007

15. Berra S, Hauser L, Audisio Y, Mántaras J, Nicora V, Oliveira MMC, et al. Validez y fiabilidad de la versión argentina del PCAT-AE para evaluar la atención primaria de salud. Rev Panam Salud Publica. 2013;33(1):30-9.

16. Berra S, Audisio Y, Mántaras J, Nicora V, Mamondi V, Starfield B. Adaptación cultural y al sistema de salud argentino del conjunto de instrumentos para la evaluación de la atención primaria de la salud. Rev Argent Salud Publica. 2011;2(8):6-14.

17. Pesse-Sorensen K, Fuentes-García A, Ilabaca J. Primary Care Assessment Tool applied to primary health care workers from Conchalí, Santiago. Rev Med Chil. 2019;147(3):305-13. doi: http://doi. org/10 .4067/S0034-98872019000300305

18. Arakawa T, Arcêncio RA, Scatolin BE, Scatena LM, Ruffi- no-Netto A, Villa TCS. Accessibility to tuberculosis treatment: assessment of health service performance. Rev Latinoam Enferm. 2011;19(4):994-1002.

19. R: A language and environment for statistical computing. Vienna: $R$ Foundation for Statistical Computing; 2020.

20. Villa TC, Ruffino-Netto A, Scatena LM, Andrade RL, Brunello ME, Nogueira JA, et al. Health services performance for TB treatment in Brazil: a cross-sectional study. BMC Health Serv Res. 2011;11(1):241. doi: http:/ / doi.org/10.1186/1472-6963-11-241

21. Wei X, Li H, Yang N, Wong SY, Owolabi O, Xu J, et al. Comparing quality of public primary care between Hong Kong and Shanghai using validated patient assessment tools. PLoS One. 2015;10(3): e0121269. doi: http://doi.org/10.1371/journal.pone.0121269

22. Mukiapini S, Bresick G, Sayed AR, Le Grange C. Baseline measures of primary health care team functioning and overall primary health care performance at Du Noon Community Health Centre. Afr J Prim Health Care Fam Med. 2018;10(1):a1458. doi: http:/ /doi. org/ 10.4102/phcfm.v10i1.1458

23. Dullie L, Meland E, Hetlevik Ø, Mildestvedt T, Kasenda S, Kantema $\mathrm{C}$, et al. Performance of primary care in different healthcare facilities: a cross-sectional study of patients' experiences in Southern Malawi. BMJ Open. 2019;9(7):e029579. doi: http://doi.org/10.1136/ bmjopen-2019-029579

24. Ki-Moon B. Building a tuberculosis-free world on a foundation of universal health coverage. Lancet. 2019;393(10178):1268-70. doi: http:/ / doi.org/10.1016/S0140-6736(19)30433-7

25. Reid MJA, Arinaminpathy N, Bloom A, Bloom BR, Boehme C, Chaisson R, et al. Building a tuberculosis-free world: The Lancet Commission on Tuberculosis. Lancet. 2019;393(10178):1331-84. doi: http:/ / doi.org/10.1016/S0140-6736(19)30024-8

26. Macinko J, Guanais FC. Population experiences of primary care in 11 Organization for Economic Cooperation and Development countries. Int J Qual Health Care. 2015;27(6):443-50. doi: http:/ / doi .org/10.1093/intqhe/mzv074

27. Giraldo-Osorio A. Instrumentos que valoran las funciones de la atención primaria de salud: perspectiva de los usuarios. Rev Salud Publica (Bogotá). 2018;20(4):498-504. doi: http://doi.org/ 10.15446rsap.V20n4.60261

28. Essa SA, Kamel MH, Mohammad OI, Shawky Ahmad NM. Assessment of the participation of primary care services in national tuberculosis control program in Gharbia Governorate. Egypt J Chest Diss Tuberc. 2017;66(2):321-5.

29. Oliveira SAC, Ruffino-Netto A, Villa TCS, Vendramini SHF, Andrade RLP, Scatena LM. Health services in tuberculosis control: family focus and community orientation. Rev Latinoam Enferm. 2009;17(3):361-7.

30. Villa TCS, Ruffino-Netto A. Questionário para avaliação de desempenho de serviços de atenção básica no controle da tuberculose no Brasil. J Bras Pneumol. 2009;35(6):610-2.

Manuscript (original in Spanish) received on 30 June 2020. Revised version accepted for publication on 6 October 2020. 


\section{Evaluación del primer nivel de atención para el control de la tuberculosis en Buenos Aires, Argentina}

RESUMEN Objetivo. Evaluar las funciones de la atención primaria de salud desde la perspectiva de los pacientes con tuberculosis (TB) provenientes de villas de emergencia de la Ciudad Autónoma de Buenos Aires, Argentina.

Métodos. Estudio observacional transversal con pacientes adultos con TB y sin TB (NoTB), residentes en villas de emergencia $(\mathrm{V})$ y fuera de ellas (NoV). La percepción de los participantes se evaluó mediante el cuestionario Primary Care Assessment Tool-usuarios (versión abreviada) que mide cuatro dimensiones principales (primer contacto, longitudinalidad de los cuidados, coordinación entre servicios e integralidad) y algunas secundarias. Se utilizó una escala de Likert, desde "No, en absoluto" (1 punto) hasta "Sí, sin duda" (4 puntos). Puntajes $\geq 3$ se consideraron como cumplimiento adecuado de las funciones. Se calcularon promedios para cada dominio y dos puntajes globales: con y sin dominios secundarios.

Resultados. Se incluyeron 83 participantes (20 TB-S, 21 TB-NV, 19 NoTB-S y 23 NoTB-NoS). Las funciones evaluadas se percibieron como no adecuadas. El grupo TB-S tuvo los puntajes globales más bajos y en ningún dominio alcanzó 3 puntos. No hubo diferencias significativas en los dominios ni los puntajes globales entre grupos. Los participantes con TB dieron menores puntajes en todos los dominios, excepto en enfoque familiar que fue significativamente mayor que los de los participantes NoTB; el puntaje global sin dominios secundarios fue menor en los participantes con TB que en los NoTB.

Conclusiones. Según la percepción de los participantes con TB y sin TB, las funciones de la atención primaria de salud no son satisfactorias, tanto dentro de las villas de emergencia como fuera de ellas.

Palabras clave Áreas de pobreza; tuberculosis; calidad de la atención de salud; atención primaria de la salud; Argentina.

\section{Avaliação da atenção primária à saúde no controle da tuberculose em Buenos Aires, Argentina}

RESUMO Objetivos. Avaliar as funções da atenção primária à saúde da perspectiva de pacientes com tuberculose (TB) provenientes de comunidades desfavorecidas na cidade de Buenos Aires, Argentina.

Métodos. Estudo observacional transversal com pacientes adultos com ou sem TB (TB, NãoTB), residentes ou não de comunidades desfavorecidas (C, NãoC). Avaliamos as percepções dos participantes utilizando questionário Primary Care Assessment Tool-usuários (versão reduzida), que mede quatro dimensões principais (primeiro contato, longitudinalidade da atenção, coordenação entre serviços e integralidade), bem como algumas dimensões secundárias. Utilizamos uma escala de Likert de 4 pontos, variando de "definitivamente não" (1 ponto) a "definitivamente sim" (4 pontos). Considerou-se que pontuações $\geq 3$ indicavam o cumprimento adequado das funções. Calculamos as médias para cada domínio e duas pontuações globais: com e sem domínios secundários.

Resultados. Ao todo, 83 participantes foram incluídos no estudo (20 TB-C, 21 TB-NãoC, 19 NãoTB-C e 23 NãoTB-NãoC). As funções avaliadas foram percebidas como inadequadas. O grupo TB-C apresentou a pontuação global mais baixa, não alcançando 3 pontos em nenhum domínio. Não houve diferenças significativas entre os grupos nos domínios nem na pontuação global. Os participantes com TB deram pontuações mais baixas em todos os domínios, exceto no enfoque familiar, no qual a pontuação foi significativamente mais alta que a dos participantes sem TB; a pontuação global sem domínios secundários foi mais baixa nos participantes com TB que nos sem TB.

Conclusões. De acordo com as percepções dos participantes com e sem TB, as funções da atenção primária à saúde são insatisfatórias, tanto dentro como fora das comunidades desfavorecidas.

Palavras-chave Áreas de pobreza; tuberculose; qualidade da assistência à saúde; atenção primária à saúde; Argentina. 